\title{
PERBANDINGAN HASIL DETEKSI PLASMODIUM SPP ANTARA CARA PEMERIKSAAN MIKROSKOPIK TETESAN DARAH TEBAL DAN TEKNIK POL YMERASE CHAIN REACTION
}

\author{
Cindy Sandra \\ Josef S. B. Tuda \\ Victor D. Pijoh \\ Bagian Parasitologi Fakultas Kedokteran Universitas Sam Ratulangi Manado
Email: blezzme19@yahoo.com
}

\begin{abstract}
Malaria is still a health problem in the world, especially in undeveloped countries. This disease is caused by protozoa of the genus Plasmodium and has two ways of transmission, naturally (Anopheles spp.) and unnaturally. WHO mentioned that in 2006 there were as many as 200-300 million cases of clinical malaria with 880,000 deaths. In 2012, it was recorded that there were a total of 8,691 malaria cases in North Sulawesi, Indonesia. Therefore, an early diagnostic tool with high sensitivity and specificity is needed. This study aimed to compare the sensitivity and specificity in detection of Plasmodium spp by using thick blood smear method to Polymerase Chain Reaction (PCR). This was a diagnostic test using blood samples of 30 malaria patients at Budi Mulia Hospital and Manembo-nembo Hospital Bitung from September 2013 - January 2014. Thick blood smears were prepared and microcopically tested, then the specimens were scrapped and be further tested by using the PCR. The microscopic test showed 20 positive samples meanwhile the PCR showed 24 positive samples. A diagnostic test using predictive table 2x2 indicated that the PCR had $100 \%$ sensitivity in general, $60 \%$ specifity, $83.3 \%$ positive predictive value, and $100 \%$ negative predictive value. Conclusion: Compared to the thick blood smear, the PCR was better in detecting plasmodia in malaria cases with a moderate specificity value and a high sensitivity value.
\end{abstract}

Keywords: thick blood smear, Polymerase Chain Reaction (PCR), sensitivity, specificity

\begin{abstract}
Abstrak: Malaria merupakan salah satu penyakit yang masih menjadi masalah kesehatan di dunia terutama di negara-negara yang belum berkembang. Malaria disebabkan oleh protozoa dari genus Plasmodium dan ditularkan melalui dua cara yaitu alamiah melalui nyamuk Anopheles spp. dan tidak alamiah. WHO melaporkan bahwa pada 2006 terdapat 200-300 juta kasus malaria dengan 880.000 kematian. Di Provinsi Sulawesi Utara, Indonesia, dilaporkan total kasus malaria tahun 2012 sebesar 8.691. Oleh karena itu diperlukan suatu alat diagnostik dini dengan sensitivitas dan spesifisitas yang baik. Penelitian ini bertujuan untuk membandingkan tingkat sensitivitas dan spesifisitas hasil deteksi Plasmodium spp antara cara pemeriksaan mikroskopik tetesan darah tebal dan teknik Polymerase Chain Reaction (PCR). Penelitian ini merupakan uji diagnostik dengan sampel darah dari 30 pasien malaria di RS Budi Mulia dan RS Manembo-nembo Bitung sejak September 2013 - Januari 2014. Setelah disiapkan tetesan darah tebal, dilakukan pemeriksaan mikroskopik. Selanjutnya, spesimen darah dikerok dan diperiksa dengan PCR. Hasil pemeriksaan mikroskopik menunjukkan 20 sampel positif malaria sedangkan pemeriksaan PCR 24 sampel positif malaria. Tes uji diagnostik dengan tabel prediktif 2x2 mendapatkan tingkat sensitivitas PCR secara umum sebesar $100 \%$, spesifisitas $60 \%$, nilai duga positif $83,33 \%$, dan nilai duga negatif $100 \%$. Simpulan: Dibandingkan tetesan darah tebal, pemeriksaan PCR dapat mendeteksi secara
\end{abstract}


lebih baik adanya plasmodia pada kasus malaria, dengan nilai spesifitas sedang dan nilai sensitivitas tinggi.

Kata kunci: tetesan darah tebal, Polymerase Chain Reaction (PCR), sensitivitas, spesifisitas

Malaria merupakan masalah kesehatan di dunia terutama di negara-negara yang secara ekonomis masih tertinggal dan belum berkembang. Di Indonesia, malaria sering menyebabkan kematian pada bayi, balita, ibu hamil, dan orang dewasa. ${ }^{1,2}$ Malaria menduduki ranking 5 dari 10 penyakit utama penyebab kecacatan dan kematian di negara-negara paling miskin di dunia. ${ }^{3}$

Malaria disebabkan oleh protozoa dari genus Plasmodium yang menyerang eritrosit dan ditandai dengan ditemukannya bentuk aseksual dalam darah. Pada manusia, malaria dapat disebabkan oleh Plasmodium falciparum, Plasmodium vivax, Plasmodium ovale, dan Plasmodium malariae. ${ }^{4}$ Malaria ditularkan melalui dua cara yaitu: secara alamiah (Anopheles spp.) dan tidak alamiah (malaria bawaan). ${ }^{5}$

Menurut World Health Organization, pada tahun 2006 terdapat 200-300 juta kasus malaria dan lebih dari 880.000 kematian terjadi akibat malaria. ${ }^{1}$ Di Indonesia, khususnya Provinsi Sulawesi Utara, ditemukan pada tahun 2012 terdapat 8.691 kasus yang positif malaria. ${ }^{6}$

Dalam menurunkan prevalensi malaria yang terus meningkat diperlukan alat uji diagnostik dengan akurasi yang tinggi. Sampai sekarang diagnosis laboratorium yang masih digunakan sebagai standar emas di seluruh dunia ialah tetesan darah tebal maupun tipis. Tetesan darah tebal merupakan cara terbaik untuk mendapatkan parasit malaria karena jumlah tetesan darah yang diberikan cukup banyak dibandingkan tetesan darah tipis. Prosedur ini sangat sederhana dan murah, namun pengerjaannya membutuhkan kerja yang intensif dan tenaga kerja yang trampil. Selain itu, pada keadaan daerah dengan transmisi yang stabil bisa didapatkan hasil negatif dalam pemeriksaan mikroskopik tetapi belum dapat dipastikan apakah darah penderita sudah bebas parasit malaria.,
Sejalan dengan perkembangan teknologi yang semakin canggih diperkenalkan teknik baru yaitu Polymerase Chain Reaction (PCR) yang merupakan teknik in vitro untuk memperbanyak DNA spesifik secara enzimatik pada suatu sikuen DNA yang telah diketahui. Dalam penelitian ini digunakan sekuens genus gen SSUrRNA yang dapat mendeteksi plasmodium pada stadium seksual dan aseksual hingga pada tahap membedakan spesies plasmodium.

Hingga kini PCR masih merupakan pemeriksaan yang lebih sensitif dan spesifik daripada pemeriksaan mikroskopik, terutama pada kasus malaria dengan jumlah parasit yang rendah dalam darah atau adanya infeksi gabungan antara plasmodium. ${ }^{8-10}$

Untuk meningkatkan akurasi, sebaiknya pemeriksaan mikroskopik tetesan darah tebal dilanjutkan dengan metode PCR. Hal ini dapat membantu pasien untuk terobati secara lebih tepat dan menurunkan angka rekurensi. ${ }^{11}$

Penelitian ini bertujuan untuk membandingkan hasil deteksi Plasmodium spp. antara cara pemeriksaan mikroskopik tetesan darah tebal dan teknik PCR.

\section{METODE PENELITIAN}

Penelitian ini merupakan penelitian uji diagnostik dengan sampel darah dari sejumlah 30 pasien malaria dengan gejala trias malaria di RS Budi Mulia dan RS Manembo-nembo Bitung sejak bulan September 2013 - Januari 2014. ${ }^{12}$

Sampel darah tersebut dibuat sedian tetesan darah tebal yang diperiksa dengan mikroskopik. Tetesan darah kemudian dikerok dan dilakukan pemeriksaan dengan PCR di Laboratorium Parasitologi Fakultas Kedokteran Universitas Sam Ratulangi Manado. Pemeriksaan PCR menggunakan metode Promega, begitu juga dalam hal ekstraksi DNA. 
Hasil pemeriksaan mikroskopik dan PCR dalam mendeteksi Plasmodium spp. menjadi variabel yang diukur, meliputi jum-lah true positive (TP), jumlah true negative (TN), jumlah false positive (FP), dan jumlah false negative (FN). TP ialah jumlah sampel yang dideteksi positif dengan pemeriksaan mikroskopik dan digolongkan positif dengan pemeriksaan PCR. TN ialah jumlah sampel yang dideteksi negatif dengan pemeriksaan mikroskopik dan digolongkan negatif oleh pemeriksaan PCR. FP ialah jumlah sampel yang dideteksi negatif dengan pemeriksaan mikroskopik dan digolongkan positif oleh pemeriksaan PCR. FN ialah jumlah sampel yang dideteksi positif dengan pemeriksaan mikroskopik dan digolongkan negatif oleh pemeriksaan PCR. Nilai tersebut kemudian ditabulasi menggunakan Microsoft Exel 2007 dan dilakukan pengolahan data uji diagnostik untuk mengetahui tingkat sensitivitas dan spesifisitas menggunakan tabel $2 \times 2$. Untuk mendapatkan besar sensitivitas digunakan rumus $\mathrm{TP} /(\mathrm{TP}+\mathrm{FN})$ $\mathrm{x} 100 \%$; spesifitas dengan rumus $\mathrm{TN} /(\mathrm{TN}+\mathrm{FP}) \times 100 \%$; nilai prediktif positif $\mathrm{TP} /(\mathrm{TP}+\mathrm{FP}) \quad \times 100 \%$; dan nilai prediktif negatif $\mathrm{TN} /(\mathrm{TN}+\mathrm{FN}) \times 100 \% .^{13}$

\section{HASIL PENELITIAN}

Pada uji diagnostik ini didapatkan hasil sensitivitas, spesifisitas, nilai duga positif dan nilai duga negatif dari tetesan darah tebal yang diperiksa secara mikroskopik dan PCR (Tabel 1).

Tabel 1. Hasil uji diagnostik pada Tabel Nilai Prediktif $2 \times 2$

\begin{tabular}{ccccc}
\hline & & \multicolumn{2}{c}{ Mikroskopik } & \\
\cline { 3 - 4 } & & Positif & Negatif & \\
\hline \multirow{2}{*}{ PCR } & Positif & 20 & 4 & 24 \\
\cline { 2 - 5 } & Negatif & 0 & 6 & 6 \\
\hline \multicolumn{2}{c}{ Total } & 20 & 10 & 30 \\
\hline
\end{tabular}

\section{Sensitifitas}

$\frac{20}{20+0} \quad \times 100 \%=100 \%$

Spesifisitas

$\frac{6}{6+4} \times 100 \%=60 \%$

Nilai Duga Positif

$\frac{20}{20+4} \times 100 \%=83,33 \%$

Nilai Duga Negatif

$\frac{6}{6+0} \quad \times 100 \%=100 \%$

\section{BAHASAN}

Dari hasil penelitian yang dilakukan selama 4 bulan di RS Budi Mulia Bitung dan RS Manembo-nembo pada 30 orang pasien positif malaria secara klinik dengan pemeriksaan mikroskopik tetesan darah tebal didapatkan 24 pasien yang positif dan 6 pasien yang negatif plasmodium. Setelah dilakukan uji diagnostik terhadap sampel penelitian dengan pemeriksaan mikroskopik (standar emas) dan PCR didapatkan hasil sensitivitas sebesar $100 \%$ dan spesifitas sebesar $60 \%$.

Pada penelitian ini, sensivitas mencapai angka 100\% yang berarti PCR sangat mampu menunjukkan nilai positif pada sekelompok pasien yang benar-benar sakit malaria. Spesifitas $60 \%$ bisa dikarenakan oleh beberapa hal antara lain kesalahan pengerjaan, kontaminasi bahan, nilai ambang penglihatan dari pemeriksa dan pemilihan dalam penggunaan primer, sedangkan $40 \%$ yang sisa disebabkan karena terdapatnya 4 sampel yang termasuk dalam false positive.

Pada penelitian ini didapatkan 6 sampel yang dinyatakan negatif baik dengan pemeriksaan mikroskopik maupun dengan PCR, dan tidak ditemukan sampel yang dinyatakan positif pada pemeriksaan mikroskopik tetapi negatif pada PCR. Pada nilai prediktif positif dan negatif ditemukan 83,33\% dan $100 \%$ yang berarti sangat baik dalam memastikan bahwa jika terdapat hasil positif pada uji diagnostik berarti 
seorang pasien itu memang benar-benar sakit malaria; begitu juga sebaliknya bila pasien yang tidak menderita malaria (sangat penting bagi bagian klinik di rumah sakit).

Hasil positif yang didapat dari pemeriksaan PCR memiliki akurasi 100\%. Hal ini tidak mengartikan bahwa pemeriksaan mikroskopik tidak akurat, tetapi sebaiknya pemeriksaan mikroskopik dilanjutkan dengan PCR karena hal ini dapat membantu pasien untuk terobati dengan baik dan dapat sembuh secara total; juga dapat membantu menekan angka rekurensi.

\section{SIMPULAN}

Metode pemeriksaan Polymerase Chain Reaction dapat mendeteksi lebih baik plasmodium malaria pada darah penderita malaria dibandingkan pemeriksaan mikroskopik tetesan darah tebal, dengan nilai spesifitas sedang dan nilai sensitivitas tinggi.

\section{SARAN}

Dari hasil penelitian uji diagnostik ini dapat dipertimbangkan penggunaan PCR sebagai sarana teknik laboratorium untuk membantu menegakkan diagnosis malaria. Selain itu, penggunaan PCR juga sebagai sarana follow up pada pasien yang telah sembuh secara klinis karena DNA masih tetap terdeteksi, yang dapat mencegah terjadinya rekurensi.

\section{DAFTAR PUSTAKA}

1. Hadidjaja P, Margono SS, editors. Dasar Parasitologi Klinik. Jakarta: FKUI, 2011; p. 1-3.

2. Sutanto I, Ismid IS, Syarifudin PK, Sungkar S, editors. Parasitologi Kedokteran (Edisi Keempat). Jakarta: FKUI, 2008; p. 23-42.

3. Harijanto PN, Agung N, Carta G. Pendahuluan Malaria. In: Harijanto PN, Agung N, Carta G, editors. Malaria dari Molekular ke Klinis (Edisi Kedua). Jakarta: EGC, 2009; p.1-7.
4. Harijanto PN. Malaria. In: Sudoyo AW, Setiyohadi B, Alwi I, Simadibrata M, Setiati S, editors. Buku Ajar Ilmu Penyakit Dalam Jilid III (Edisi Kelima). Jakarta: Internapublishing, 2006; p. 1170-8.

5. Prabowo A, editor. Malaria Mencegah dan Mengatasinya (Edisi Kedua). Jakarta: Puspa Swara, 2008; p. 5-8.

6. Dinas Kesehatan Sulawesi Utara. Data Informasi Angka Kejadian Malaria Kota Bitung; 2012.

7. Gandahusa S, Ilahude HD, Pribadi W. Malaria dan Penanggulangannya. In: Gandahusa S, Illahude H, Pribadi W, editors. Parasitologi Kedokteran (Edisi Ketiga). Jakarta: FKUI, 2006; p. 39-45.

8. Neva FA, Brown HW. Treatment of Malaria. In: Franklin Neva and Harold Brown Basic Clinical Parasitology (Sixth Edition). Norwalk, Conn: Appleton \& Lange, 1994; p.83-97.

9. Berry A, Benoit VF, Fabre R, Cassaing S, Magnaval JF. PCR-Based Methods to the Diagnosis of Imported Malaria. Parasite Journal. European Multicolloquium of Parasitology. 2008;15(3):484-8.

10. Johnston SP, Pieniazek NJ, Xayafong VM, Slemenda SB, Wilkins PP, da Silva AJ. PCR as confirmatory Technique for Laboratory Diagnosis of Malaria. J Clin Miocrobiol. 2006;44(3):1087-9.

11. Arum I, Purwanto AP, Arfi S. Diagnostic Test of Plasmodium Malaria by Immunochromatographic Method Compared to Microscopic Examination. Indonesian Journal of Clinical Pathology and Medical Laboratory. 2006;12(3):118-2.

12. Sastroasmoro $S$, Ismael $S$. Penelitian diagnostik. In: Sastroasmoro S, Ismael S, editors. Dasar-dasar Metodologi Penelitian Klinis (Edisi Keempat). Jakarta: Sagung Seto, 2011; p. 49-51.

13. Sopiyudin DM. Besar sampel penelitian diagnostik. In: Sopiyudin D, editor. Penelitian Diagnostik: Dasar-dasar Teoritis dan Aplikasi dengan Program SPSS dan Stata. Jakarta: Salemba Medika, 2009; h.32-40. 